\title{
DA SACRALIZAÇÃO DA ECONOMIA À SACRALIZAÇÃO DA POLÍTICA: a Teologia da Libertação como uma versão católica de rejeição intramundana do mundo
}

Carlos Ângelo de Meneses Sousa

Curso: Doutorado em Sociologia.

Data de defesa da tese: 27 de Junho de 2005

Orientador: Prof. Dr. Eurico Antônio Gonzalez Cursino dos Santos.

\section{Resumo}

Esta tese investiga a relação entre política e religião, a partir da Teologia da Libertação. Procura compreender se a mesma é uma versão católica de rejeição intramundana do mundo, onde a ação política se constitui um indicador privilegiado de salvação.

A pesquisa priorizou o Movimento de Educação de Base (MEB) na diocese de Picos, Estado do Piauí, no Nordeste brasileiro, no período de 1993 a 1998, embora não se restrinja a ele. Possui como base teórica e metodológica a sociologia weberiana da religião.

Conclui que a rejeição intramundana do mundo na Teologia da Libertação está voltada para a política e que os católicos ficam mais certos de sua saúde soteriológica quanto mais tiverem uma ação política no mundo em vista da justiça social.

Palavras-chave: política, Teologia da Libertação, rejeição intramundana do mundo, catolicismo, racionalismo, religiosidade. 